\title{
The Analysis of Concepts Comprehension in Scie nce Subject Matter of the Fourth Grade Students in Group II Banjar Sub- district
}

\author{
Widiawati, Ni Putu \\ Ganesha University of Education \\ widia_wati10@yahoo.co.id
}

\begin{abstract}
This study was aimed at describing students' concept knowledge in science. Three elementary schools around cluster II in Banjar subdistrict such as SD Negeri 1 Temukus, SD Negeri 4 Temukus, and SD Negeri 5 Temukus were used as the sites of this study. The subject of this study was fourth grade students and elementary teachers in each school, while the object was students' concept knowledge in science, the activities conducted to improve their comprehension, and the obstacles faced by students. The data of students' science concept knowledge were collected through tests and interview. The result of this study showed that $10.81 \%$ of students got the average scores from the test, around $45.95 \%$ of students got low scores, and around $43.24 \%$ of students got high scores. Meanwhile, the result of indicator analysis pointed on the highest category (around 88.92\%) from indicator of giving example and the lowest category from indicator of explaining $(60.81 \%)$. Based on the result of interview, it was known that the activities conducted to improve students' concept knowledge in science were by doing learning activities which students were interested with such as group discussion, project, observation, and experiment. It was also known that the students faced some obstacles in comprehending the concept such as low motivation of students, inadequate of learning facilities, and less interesting learning methods used.
\end{abstract}

keywords: descriptive qualitative, science, concept knowledge

\section{Introduction}

Based on Undang-Undang No. 20 Tahun 2003 about Sistem Pendidikan Nasional, the education is aimed at developing students potential to be faithful and god-fearing human to God, having good character, healthy, bookish, competent, creative, independent, democratic and responsible citizen. This explanation argues that the education is a conscious and planned effort to create a learning situation and learning process for the students to be active in developing their interest and competency optimally to be useful humans for themselves and their country. Considering the importance of education for a country, it is a must to pay attention towards its quality improvement. Improving the quality of education means improving the quality of human source. The high quality of education is needed to support the creation of good quality and competent human source in this era globalization. One of the education fields that should be considered in knowledge and technology development is science.

Science is one of the main subjects in the curriculum in Indonesia, included in elementary level of education. Science is a knowledge about development of thinking and analysis so that every problem related to nature can be comprehended. Fowler \& Fowler (in Ardana, 2013: 2) define science as a knowledge with the relation of material events and generally it is based on the result of observation, experiment, and induction. Naturally, this subject has a concept of thinking and comprehension which is integrated in systematic and analytic thinking ability development. Thus, science should be introduced early, that is since elementary level to a higher level of education.

Through science, students are expected to have the ability to think inductively with a variety of science concepts and principles. This ability is expected to be used to describe natural the phenomenon in daily life, apply the science principles with technology, developing scientific behavior and attitude to discover and improve the concept knowledge. 
The concept knowledge has an important role in teaching and learning process and be considered as the basis in achieving the goals. According to Tjandra dkk. (2005), concept is a conclusion of definition consisting of two or more facts with the same features. To put the concept in a lesson, the teachers need to teach it in real context by linking it with the environment. It affects on the development of students' critical thinking and the improvement of their knowledge towards the material being learned.

Based on the result of the observation and interview in class IV of cluster II in Banjar subdistrict, it was found the average scores of students' science middle test as presented in table 1 below.

Table 1. The average scores of fourth grade students' science middle test in cluster II of Banjar subdistrict

\begin{tabular}{cccc}
\hline No & School & $\begin{array}{c}\text { Standard of } \\
\text { Minimum }\end{array}$ & Average \\
\hline 1 & SD Neregri 1 Temukus & 60 & 58.0 \\
\hline 2 & SD Negeri 4 Temukus & 64 & 72.6 \\
\hline 3 & SD Negeri 5 Temukus & 62 & 79.0 \\
\hline 4 & SD Negeri 1 Tigawasa & 62 & 63.5 \\
\hline 5 & SD Negeri 1 Tigawasa & 60 & 69.8 \\
\hline 6 & SD Negeri 1 Tigawasa & 61 & 73.3
\end{tabular}

The table above shows the different average scores of the fourth grade students' middle test in cluster II in Banjar subdistirct. Some of the students got low average, some got adequate average, and some got high average scores. This different average score in each school was caused by several things. First, some of the students got the concept knowledge by being involved in meaningful learning activities - such as doing experiments, demonstrations, and/or using relevant media to learn - and some of the students did not.

Second, among 6 (six) schools in cluster II in Banjar subdistrict, some of the learning approaches used were oriented on conventional approaches and some on cooperative approaches. In conventional approach, the methods used were lecturing, question and answer, noting, listening to teacher, and assignment. The teachers used lecturing method in explaining the concept of science to students by asking them to listen to, take a note, and memorize. This method could decrease the students' scientific attitude and make them passive during their learning process. In cooperative approach, the students were asked to show their creativity in learning like group discussion and project task. Those activities help the students to explore their ability in thinking critically and giving opinion. Thus, SD Negeri 1 Temukus was chosen as school with the low average score, SD Negeri 4 Temukus with the adequate average score, and SD Negeri 5 Temukus with the high average score.

The students in the schools tended to be interested with the simple problems that were found around their environment (Astawan, 2012). Those problems would give them opportunity to develop their critical and objective thinking in solving the problems. For this reason, science subject in schools must be oriented on meaningful activities such as simple investigation, discussion, and direct observation in the environment. Such learning activities would attract students' interest and improve their curiosity so that their concentration improves. It enables the students to comprehend the materials given by the teachers. The concept knowledge obtained from critical thinking activity by constructing their knowledge will stand longer as well as be a good foundation for students to learn the other concepts and improve the understanding towards the materials.

Based on this explanation, this study focuses on describing 1) fourth grade students' science concept in cluster II in Banjar subdistrict, 2) the activities to improve students' knowledge, and 3) the obstacles faced by teachers and students in comprehending the concept. 


\section{Research Methods}

This study used qualitative research method. This method was used because 1) it was easy to adjust this study with the reality, 2) it was easy to connect the researcher with the research subject, and 3) it had sensitivity and adaptation from the effects of the values (Zuriah, 2012).

This study was done in elementary schools in cluster II around Banjar subdistrict such as SD Negeri 1 Temukus, SD Negeri 4 Temukus, and SD Negeri 5 Temukus. The subject of this study was science teachers and students in the three schools. While the object of the study included students' concept knowledge in science, the activities done to improve the students' knowledge, and the obstacles face in comprehending the concept.

The data were collected through observation, test, and interview. The test used to collect the data of students' knowledge was essay test consisting of 10 items. The test was made based on the indicators of the concept including interpretation, giving example, classification, summarization, prediction, comparison, and explanation. Meanwhile, the interview type used was semistructured interview with 10 items. The interview was done with all science teachers and fourth grade students. Around three students which were chosen as representative of low average group, adequate average group, and high average group were interviewed.

The instruments were validated before being used to collect the data. The validation was done in form of try out to find out its feasibility in collecting the expected data. The try out was delivered to 48 students spread out in SD Negeri 1 Temukus and SD Negeri 5 Temukus. The result of this try out was then analyzed to find out its validity, reliability, index of discriminancy, and index of difficulty. Based on the result, all items were valid and could be used to collect the data.

The collected data were then analyzed using statistic descriptive analysis including mean, median, modus, maximum data, minimal data, variances, standard deviation, and range. The data were also analyzed using descriptive percentage to find out the percentage of the knowledge in each indicator.

\section{Finding}

\section{Findings and Discussion}

The concept knowledge test given to the students showed different result. The result is presented in the table below.

Table 2. Frequency distribution of the fourth grade students' science concept knowledge in SD Negeri 1 Temukus

\begin{tabular}{ccccc}
\hline No & Range & $\begin{array}{c}\text { Middle } \\
\text { score }\end{array}$ & Frequency & $\mathbf{F}_{\text {relative }}(\boldsymbol{\%})$ \\
\hline 1 & $59-64$ & 61.5 & 6 & 18.75 \\
\hline 2 & $65-70$ & 67.5 & 7 & 21.87 \\
\hline 3 & $71-76$ & 73.5 & 3 & 9.37 \\
\hline 4 & $77-82$ & 79.5 & 7 & 21.87 \\
\hline 5 & $83-88$ & 85.5 & 5 & 15.62 \\
\hline 6 & $89-94$ & 91.5 & 4 & 12.5 \\
\hline & Jumlah & & $\mathbf{3 2}$ & $\mathbf{1 0 0}$ \\
\hline
\end{tabular}

Based on the table above, it is seen that the mean is about 75,4 located in the range of 71 - 76. The total of students who obtained the average scores were about 9,37\%, the students who obtained low average scores were 40,62\%, and students who obtained high average scores were $49,99 \%$.

The data of students' concept knowledge in SD Negeri 4 Temukus are presented 
below.

Table 3. Frequency distribution of the fourth grade students' science concept knowledge in SD Negeri 4

Temukus

\begin{tabular}{ccccc}
\hline No. & Range & $\begin{array}{c}\text { Middle } \\
\text { score }\end{array}$ & Frequency & F $_{\text {relative }}(\boldsymbol{\%})$ \\
\hline 1 & $58-64$ & 61 & 4 & 16 \\
\hline 2 & $65-71$ & 68 & 6 & 24 \\
\hline 3 & $72-78$ & 75 & 3 & 12 \\
\hline 4 & $79-85$ & 82 & 5 & 20 \\
\hline 5 & $86-92$ & 88 & 1 & 4 \\
\hline 6 & $93-99$ & 96 & 6 & 24 \\
\hline & Jumlah & & $\mathbf{2 5}$ & $\mathbf{1 0 0}$ \\
\hline
\end{tabular}

Based on table 3, it is concluded that the mean is 78,04 located in the range of $72-$ 78. The total of students who obtained the average scores were about $12 \%$, the students who obtained low average scores were $40 \%$, and students who obtained high average scores were $48 \%$.

The data of students' concept knowledge in SD Negeri 5 Temukus are presented below.

Table 4. Frequency distribution of the fourth grade students' science concept knowledge in SD Negeri 5

Temukus

\begin{tabular}{ccccc}
\hline No. & Range & $\begin{array}{c}\text { Middle } \\
\text { score }\end{array}$ & Frequency & F $_{\text {relative }}(\boldsymbol{\%})$ \\
\hline 1 & $61-67$ & 64 & 4 & 23.53 \\
\hline 2 & $68-74$ & 71 & 3 & 17.65 \\
\hline 3 & $75-81$ & 78 & 4 & 23.53 \\
\hline 4 & $82-88$ & 85 & 3 & 17.65 \\
\hline 5 & $89-95$ & 92 & 3 & 17.65 \\
\hline & Jumlah & & $\mathbf{1 7}$ & $\mathbf{1 0 0}$ \\
\hline
\end{tabular}

Based on table 4, it is concluded that the mean is 77.2 located in the range of $75-81$. The total of students who obtained the average scores were about $23.53 \%$, the students who obtained low average scores were $41.18 \%$, and students who obtained high average scores were $35.30 \%$.

The data of all students' concept knowledge in the three schools are presented below.

Table 5. Frequency distribution of the students' science concept knowledge in SD Negeri 1 Temukus, SD Negeri 4 Temukus, and SD Negeri 5 Temukus

\begin{tabular}{ccccc}
\hline No. & Range & $\begin{array}{c}\text { Middle } \\
\text { score }\end{array}$ & Frequency & F $_{\text {relative }}(\%)$ \\
\hline 1 & $59-63$ & 61 & 12 & 16.22 \\
\hline 2 & $64-68$ & 66 & 8 & 10.81 \\
\hline 3 & $69-73$ & 71 & 14 & 18.92 \\
\hline 4 & $74-78$ & 76 & 8 & 10.81 \\
\hline 5 & $79-83$ & 81 & 15 & 20.27 \\
\hline 6 & $84-88$ & 86 & 3 & 4.05 \\
\hline 7 & $89-93$ & 91 & 12 & 16.22 \\
\hline 8 & $94-98$ & 96 & 2 & 2.70 \\
\hline & Jumlah & & $\mathbf{7 4}$ & $\mathbf{1 0 0}$ \\
\hline
\end{tabular}

Based on table 5, it is concluded that the mean is 76.9 located in the range of $74-78$. 
The total of students who obtained the average scores were about $10.81 \%$, the students who obtained low average scores were $45.95 \%$, and students who obtained high average scores were $43.24 \%$.

To find out more about students' science concept knowledge, the indicators of the knowledge were analyzed such as the indicator of interpretation, giving example, classification, summarization, prediction, and explanation.

The analysis of the indicators in SD Negeri 1 Temukus showed that the indicator of giving example and comparison were the indicators with the highest percentage $(94.27 \%$ and $86.46 \%$ ). Meanwhile the indicator of summarization and explanation were the indicators with the lowest percentage $(53.12 \%$ and $52.08 \%)$. The rest of the indicators such as interpretation, classification, prediction, and explanation showed quiet high percentage which were about $72 \%-79 \%$.

The analysis of the indicators in SD Negeri 4 Temukus showed that the indicator of prediction was the indicator with the highest percentage for about $89.33 \%$. Meanwhile the indicator of explanation was the indicator with the lowest percentage for about $65.33 \%$. The rest of the indicators such as interpretation, giving example, classification, summarization tended to be quiet high with the percentage of $72 \%-79 \%$.

The analysis of the indicators in SD Negeri 5 Temukus showed that the indicator of comparison was the indicator with the highest percentage of 97.05\%. Meanwhile the indicator of summarization and clasification were the indicators with the lowest percentage of $62.74 \%$ and $63.72 \%$ ). The rest of the indicators such as interpretation, giving example, prediction, and summarization showed quiet high percentage which were around $70 \%-90 \%$.

To understand the comparison for each indicator about students' knowledge in SD Negeri 1 Temukus, SD Negeri 4 Temukus, and SD Negeri 5 Temukus can be seen in table 6 below.

Table 5. Frequency distribution of the students' science concept knowledge in SD Negeri 1 Temukus, SD Negeri 4 Temukus, and SD Negeri 5 Temukus

\begin{tabular}{ccccc}
\hline No. & Indicators & $\begin{array}{c}\text { SD N 1 } \\
\text { Temukus (\%) }\end{array}$ & $\begin{array}{c}\text { SD N 4 } \\
\text { Temukus (\%) }\end{array}$ & $\begin{array}{c}\text { SD N 5 } \\
\text { Temukus (\%) }\end{array}$ \\
\hline 1 & Interpretation & 76.04 & 85.33 & 70.59 \\
\hline 2 & $\begin{array}{c}\text { Giving } \\
\text { example }\end{array}$ & 94.27 & 84.67 & 80.39 \\
\hline 3 & Classification & 76.04 & 76.67 & 63.72 \\
\hline 4 & Summarization & 53.12 & 74.67 & 62.74 \\
\hline 5 & Prediction & 75 & 89.33 & 94.12 \\
\hline 6 & Comparison & 86.46 & 73.33 & 97.05 \\
\hline 7 & Explanation & 52.08 & 65.33 & 70.59 \\
\hline
\end{tabular}

Based on table 6 above. it can be seen that the highest percentage of the indicator of interpretation which is found in SD Negeri 4 Temukus is around $85.33 \%$. The highest percentage of the indicator of giving example which is found in SD Negeri 1 Temukus is around $94.27 \%$. The highest percentage of the indicator of classification which is found in SD Negeri 4 Temukus is found to be around $76.67 \%$. The highest percentage of the indicator of summarization which is found in SD Negeri 4 Temukus is about $74.67 \%$. The highest percentage of the indicator of prediction which is found in SD Negeri 5 Temukus is about $94.12 \%$. The highest percentage of the indicator of comparison which is found in SD Negeri 5 Temukus is about $97.05 \%$. The highest percentage of the indicator of explanation which is found in SD Negeri 5 Temukus is about $70.59 \%$.

The result of the analysis for each indicator in SD Negeri 1 Temukus, SD Negeri 4 Temukus, and SD Negeri 5 Temukus can be seen in table 7 below. 
Table 7. The result of analysis for each indicator in SD Negeri 1 Temukus, SD Negeri 4 Temukus, and SD

\begin{tabular}{cccc}
\multicolumn{5}{c}{ Negeri 5 Temukus } \\
\hline No. & Indicators & Percentage $\mathbf{\%})$ & Category \\
\hline 1 & Interpretation & 77.93 & High \\
\hline 2 & Giving example & 87.84 & High \\
\hline 3 & Classification & 73.42 & High \\
\hline 4 & Summarization & 62.61 & Average \\
\hline 5 & Prediction & 84.23 & High \\
\hline 6 & Comparison & 84.46 & High \\
\hline 7 & Explanation & 60.81 & Average
\end{tabular}

Based on the table 7 above, the indicator of giving example is the highest percentage which is about $87.84 \%$. Meanwhile, the indicator of explanation and summarization are the indicators with the lowest percentage of $60.81 \%$ and $62.61 \%$. The indicators of the knowledge such as interpretation, classification, prediction, and comparison obtain quiet high percentage which are around $70 \%-80 \%$.

\section{Discussion}

In improving the science concept knowledge, especially the indicator of explanation, giving project is the only one that can be done to give meaningful learning experience. In project, students will be asked to make a product individually and in group. The students' product will be presented and explained in front of the class, so that their ability in explaining a concept will increase but the indicator of giving example should be maintained and improved.

Besides the test, the result of the interview in each school showed that the activities done to improve students' knowledge was by conducting interesting activities such as outdoor activities. It was supported by the science teacher's statement. P : What kinds of activities do you do to improve students' knowledge in science? Have you ever done outside activities such as observation and experiment? R2 : I have done outdoor activities, but the obstacle is the process of those activities is time-consuming while the time of learning process in class is limited. For experiment activity, I have not done it yet because of lack facilities that support this activity.

The obstacles faced in comprehending the knowledge, especially in science can be seen from the interview. P : What are the obstacles faced by students in obtaining their science knowledge? R3 : The obstacles are lack ability of students in making use of the environment as their knowledge source. Besides, students often memorize the concept they learn so that the ability is still on recalling level. They also have low motivation and the facilities provided by the schools are still less adequate.

Based on the result of test done in SD Negeri 1 Temukus, it was found that the highest score obtained was 93 and the lowest was 60 . The mean score was about 75,4. Among 32 students, 3 of them $(9,37 \%)$ obtained the average scores, 13 of them $(40,62 \%)$ obtained under average scores, and 16 of them $(49,99 \%)$ obtained the above average scores. The result of each indicator of the concept showed that the indicator of summarization and explanation got the lowest percentage which were about 53,12\% and 52,08\%, while the indicator of giving example was the indicator with the highest percentage $(94,27 \%)$.

Based on the result of test done in SD Negeri 4 Temukus, it was found that the highest score obtained was 97 and the lowest was 60 . The mean score was about 78,04. Among 25 students, 3 of them (12\%) obtained the average scores, 10 of them (40\%) obtained under average scores, and 12 of them (48\%) obtained the above average scores. The result of each indicator of the concept showed that the indicator of explanation got the lowest percentage which were about $65,33 \%$, while the indicator of prediction was the indicator with the highest 
percentage $(89,33 \%)$.

Based on the result of test done in SD Negeri 5 Temukus, it was found that the highest score obtained was 93 and the lowest was 63 . The mean score was about 77,2. Among 17 students, 4 of them $(23,53 \%)$ obtained the average scores, 7 of them $(41,18 \%)$ obtained under average scores, and 6 of them $(35,30 \%)$ obtained the above average scores. The result of each indicator of the concept showed that the indicator of summarization got the lowest percentage which was about $62,74 \%$, while the indicator of comparison was the indicator with the highest percentage $(97,05 \%)$.

The result of the test in these three schools showed that the highest score was 97 and the lowest was 60 and the mean score was 75,9. Among 74 students, 8 of them $(10,81 \%)$ obtained the average scores, 34 of them $(45,95 \%)$ obtained under average scores, and 32 of them $(43,24 \%)$ obtained the above average scores. The result of each indicator of the concept showed that the indicator of explanation got the lowest percentage which was about $60,81 \%$ obtained by 45 students, while the indicator of giving example was the indicator with the highest percentage $(97,05 \%)$ obtained by 65 students. To improve students' knowledge, especially the indicator of explanation, one way that can be done is by giving project task. In this project, students were asked to explain their project in front of the class.

Susanto (2012:171) states that the direct experience in science through observation, discussion, and investigation can increase students' scientific attitude and critical thinking. The result of interview in these schools indicated that the activities that could be done to improve students' knowledge were by conducting meaningful learning activities inside and outside the class. Indoor activities that could attract students' attention were group discussion and project task, while the outdoor activities that could be done were observation and simple investigation. The indoor activities conducted by teachers and students in the class did not only help the students think creative and innovative, but also accustomed them to work together with their friends as a team. The example of project task was to make toy rocket for the material of energy and its change. The teachers asked the students to prepare the tools before they conducted the activity in class, then they cooperatively worked on that project.

The outdoor activities were the learning activities that could be done during science class. It is because this subject has a direct connection to the surrounding environment as the place of students' learning. One of the activities that could be done was observation. This activity demanded the students to observe their environment directly to get the information needed. The outdoor activity like this could improve students' interest and curiosity in learning. Besides, such activity will help students comprehend the concept meaningfully, rather than just memorize it. Therefore, the learning activities done inside or outside the class affect on students' knowledge towards the material being learned.

Sulaeman (in Budiarti, 2014) states that the students do not respect the teachers who teach using conventional methods and thus they do not pay attention. It could affect on students' activeness during their learning process. They would be passive and not care with the monotone learning situation which is dominated by their teachers. The learning activities are not flexible where only teachers ask question and students answer. The learning process which was oriented on memorization would turn students' creativity out in making use of their environment as their learning source. The students' comprehension towards the knowledge will be low because they are demanded to memorize the concept not comprehend it. This is based on the result of the interview which showed the obstacles faced by teachers and students in comprehending the material. The obstacles were the high frequency of teachers using lecturing method in explaining the concept and high frequency of students in memorizing the concept. Besides, other obstacles faced were the low motivation of students in learning, less adequate facilities provided such as books and media, and less attention of making use of the environment as the learning source. 


\section{Conclusion}

Based on the research problems and the discussion above, it can be concluded that the students' concept knowledge in cluster II in Banjar subdistrict especially in SD Negeri 1 Temukus, SD Negeri 4 Temukus, and SD Negeri 5 Temukusis was sufficient enough with the average score of 75,9. The indicator comprehension of the concept tended to be good. The indicator with the lowest score was the indicator of explaining with the percentage of $60,81 \%$, while the indicator with the highest score was the indicator of giving example with the percentage of $87,84 \%$. The activities that were needed to help students improve their knowledge were the interesting activities done outside the class. These activities could be in form of observation and experiment. The obstacles faced by students in comprehending the material were low motivation of students, less adequate facilities, lecturing-oriented teaching method by teachers, boring activities conducted, class-based learning activities, and less utilization of the environment as learning source.

Therefore it is suggested that 1) the students' concept knowledge in science needs to be improved because it has an important rules in deciding the quality of students' learning, 2) the science teachers, especially in SD Negeri 4 Temukus, are suggested to use teaching methods which are more varied and conduct meaningful learning activities for students, 3) the science teachers in SD Negeri 1 Temukus are suggested to make use of the facilities provided in schools in delivering the concept for students, 4) the stakeholders in SD Negeri 5 Temukus are suggested to provide the facilities such as books and learning media needed to support the learning process, 5) the students are suggested to improve their knowledge in science by utilizing their environment as their learning source, 6) the other researchers are also suggested to conduct further research to find out more accurate result.

\section{References}

Ardana, I Ketut. (2009). Pendidikan IPA di Sekolah Dasar. (Science in Elementary School) Singaraja: Ganesha University of Education.

Astawan, I Gede. (2013). Pendidikan IPA SD. (Science in Elementary School). Singaraja: Ganesha University of Education.

Budiarti, Yudha. (2014). Pengaruh Model Pembelajaran Clis Terhadap Hasil Belajar Ipa Siswa Kelas IV SD Di Gugus III Kecamatan Busungbiu. (The Effect of Clis Learning Model toward Science Learning Result of the Fifth Grade Students of Elementary School in Group III Busungbiu Sub-district). Thesis. Ganesha University of Education, Singaraja.

Susanto, Ahmad. (2012). Teori Belajar dan Pembelajaran Di Sekolah Dasar. (Learning and Instruction Theories in Elementary Schools). Jakarta: Kencana Prenadamedia Group.

Tjandra \& dkk. (2005). Pendidikan Ilmu Pengetahuan Sosial Di Sekolah Dasar. (Social Education in Elementary Schools). Singaraja: Ganesha University of Education.

Zuriah, Nurul. (2005). Metodologi Penelitian Sosial Dan Pendidikan. (Methodology of Social Study and Education). Jakarta: Bumi Aksara. 